\title{
Estimasi permintaan indeks harga saham gabungan di Indonesia
}

\author{
Ade Nugraha Paer*; Syamsurijal Tan; Emilia \\ Prodi Ekonomi Pembangunan, Fak. Ekonomi dan Bisnis, Universitas Jambi \\ *E-mail korespodensi: ade.nugraha.paer@gmail.com
}

\begin{abstract}
The purpose of this study is (a) to see the development of the composite stock price index, exchange rate, inflation, interest rates, and the money supply in Indonesia. (b) analyze the effect of the exchange rate, inflation, interest rate, and money supply on the composite stock price index in Indonesia. The method used in this study is a quantitative descriptive method with multiple linear regression analysis tools using the Ordinary Least Square (OLS) method. The data used is in the form of a time series. The results of this study average the development of the composite stock price index by 0.22 percent, the exchange rate by 2.57 percent, inflation by -0.90 percent, interest rates by -2.73 percent, and the Money Supply by 0.06 percent. Based on the results of the analysis conducted, exchange rates and interest rates have a negative and significant effect on the composite stock price index, inflation and the money supply have a positive and significant effect on the composite stock price index.
\end{abstract}

Keywords: Composite stock price index, Exchange rate, Inflation, Interest rates, Money supply.

\begin{abstract}
Abstrak
Tujuan penelitian ini adalah (a) melihat perkembangan indeks harga saham gabungan, kurs, inflasi, suku bunga dan jumlah uang beredar di indonesia. (b) menganalisis pengaruh kurs, inflasi, suku bunga dan jumlah uang beredar terhadap indeks harga saham gabungan di Indonesia. Metode yang digunakan dalam penelitian ini adalah metode deskriptif kuantitatif dengan alat analisis model regresi linier berganda dengan metode ordinary least square $(O L S)$. Data yang digunakan berupa runtun waktu (time series). Hasil penelitian ini ratarata perkembangan indeks harga saham gabungan sebesar 0,22 persen, kurs sebesar 2,57 persen, inflasi -0,90 persen suku bunga sebesar -2,73 persen dan Jumlah Uang Beredar sebesar 0,06 persen. Berdasarkan hasil analisis yang dilakukan Kurs dan suku bunga berpengaruh secara negatif dan signifikan terhadap indeks harga saham gabungan, inflasi dan jumlah uang beredar berpengaruh secara positif dan signifikan terhadap indeks harga saham gabungan.
\end{abstract}

Kata kunci: Indeks harga saham gabungan, Kurs, Inflasi, Suku bunga, Jumlah uang beredar.

\section{PENDAHULUAN}

Pasar modal memiliki andil yang besar bagi perekonomian suatu negara. Dominasi perdagangan obligasi dalam penghimpunan dana merupakan salah satu fakta. Tidak terlalu 
berlebihan bila dikatakan bahwa perkembangan ekonomi suatu negara secara keseluruhan, harus dapat diukur dari seberapa jauh perkembangan pasar modal dan industri sekuritas pada suatu negara. Aktivitas perdagangan saham dapat dilihat dengan aktivitas volume perdagangan. Volume perdagangan merupakan jumlah lembar saham yang diperjual belikan pada periode tertentu di pasar modal. Volume perdagangan yang tinggi di pasar dapat ditafsirkan bahwa pasar modal negara tersebut membaik keadaanya. Dengan membaiknya pasar modal, perekonomian dari negara tersebut juga ikut membaik karena pasar modal dapat menunjang perkembangan perekonomian di negara tersebut (Husnan, 2015).

Pasar modal menjalankan dua fingsi sekaligus, yakni sebagai fungsi ekonomi dan fungsi keuangan. Dalam menjalankan fungsi ekonomi, pasar modal menyediakan fasilitas untuk memindahkan dana dari pihak yang kelebihan dana ke pihak yang memerlukan dana. Dengan menginvestasikan kelebihan dana yang dimiliki berharap akan memperoleh imbalan dari penyerahan dana tersebut. Sedangkan pihak yang memerlukan dana akan menggunakan dana tersebut untuk kepentingan investasi tanpa harus menunggu tersedianya dana. Dalam menjalankan fungsi keuangan, pasar modal menyediakan dana yang diperlukan oleh pihak yang memerlukan dana, sementara pihak yang memiliki kelebihan dana menyediakan dana tanpa harus terlibat langsung dalam kepemilikan aktiva riil yang diperlukan untuk investasi (Husnan, 1993).

Tahun 2008 terjadi krisis keuangan dunia yang ditandai dengan kebangkrutan beberapa perusahaan besar di Amerika Serikat, hal ini terjadi karena dipicu krisis kredit perumahan dan produk sekuritas. Krisis ini ikut memengaruhi perekonomian Indonesia, salah satu indikatornya yaitu jatuhnya harga saham di pasar modal. Indeks harga saham gabungan merupakan cerminan dari kegiatan pasar modal secara umum. Peningkatan IHSG menunjukkan pasar modal sedang mengalami tren naik, sebaliknya jika menurun menunjukkan pasar modal sedang mengalami tren penurunan. Untuk itu, seorang investor harus memahami pola perilaku harga saham di pasar modal.

Menurut para pakar ekonomi, kinerja suatu pasar modal mempunyai hubungan yang kuat dengan lingkungan ekonomi makro. Ada beberapa faktor atau variabel ekonomi yang dapat memengaruhi harga saham antara lain pertumbuhan GDP, produksi industri, inflasi, tigkat suku bunga, nilai tukar rupiah, pengangguran dan anggaran defisit (Sunariyah, 2006).

Ketika terjadi perubahan pada faktor makroekonomi, investor akan mengkalkulasi dampaknya baik yang positif maupun yang negatif terhadap kinerja perusahaan beberapa tahun kedepan, kemudian mengambil keputusan membeli atau menjual saham yang bersangkutan. Oleh karena itu, harga saham lebih cepat menyesuaikan diri daripada kinerja perusahaan terhadap perubahan variabel mekroekonomi (Samsul, 2008).

IHSG berubah setiap hari karena perubahan harga pasar yang terjadi setiap hari dan adanya saham tambahan. Pertambahan jumlah saham beredar berasal dari emisi baru, yaitu masuknya emiten baru yang tercatat di bursa efek atau terjadi tindakan aksi korporasi berupa waran, deviden saham, saham bonus, dan saham konversi. Perubahan harga saham individu di pasar terjadi karena faktor permintaan dan faktor penawaran. Terdapat berbagai variabel yang mempengaruhi permintaan dan penawaran, baik yang rasional maupun yang irrasional. Pengaruh yang sifatnya rasional mencakup kinerja perusahaan, tingkat buga, tingkat inflasi, tingkat pertumbuhan kurs valuta asing, dan indeks harga saham dari negara lain. Pengaruh yang irrasional mencakup rumor dipasar, permainan harga. Pada umumnya, 
kenaikan harga dan penurunan dapat terjadi secara bersama-sama. Jika harga naik, maka akan diikuti dengan penurunan harga pada periode berikutnya (Samsul, 2006).

Dipasar sebuah indeks diharapkan memiliki lima fungsi yaitu sebagai indikator trend pasar, sebagai indikator tingkat keuntungan, sebagai tolak ukur kinerja suatu portofolio, memfasilitasi pembentukan portofolio dengan strategi pasif, dan memfasilitasi berkembangnya produk deriatif (Darmadji dkk, 2012). Didalam pasar modal banyak terdapat instrumen yang ditawarkan, antara lain saham, obligasi, derivatif dan reksadana. Setiap instrumen memiliki karakteristik keuntungan dan resiko yang berbeda-beda antara satu dan yang lainnya (Martalena dan Marlinda, 2011). Saham merupakan salah satu instrumen pasar keuangan yang paling populer. Menerbitkan saham merupakan salah satu pilihan ketika memutuskan untuk pendanaan. Pada sisi yang lain, saham merupakan instrumen investasi yang banyak dipilih oleh para investor karena saham mampu memberikan tingkat keuntungan yang menarik.

Menurut teori yang belum konsisten antara pengaruh faktor makroekonomi terhadap IHSG maka penulis tertarik membahas masalah tersebut dalam penelitian ini yang berjudul "Estimasi Permintaan Indeks Harga Saham Gabungan di Indonesia"

Adapun tujuan penelitian ini yaitu menganalisis perkembangan kurs, inflasi, suku bunga dan jumlah uang beredar terhadap indeks harga saham gabungan di indonesia serta menganalisis pengaruh kurs, inflasi, suku bunga dan jumlah uang beredar terhadap indeks harga saham gabungan selama periode 1997-2018.

\section{METODE}

Dalam penelitian ini penulis menggunakan penelitian deskriptif kuantitatif, Data yang digunakan dalam penelitian ini merupakan data sekunder yang merupakan data berkala dari tahun $1997-2018$.

\section{Analisa deskriftif}

Analisis deskriptif adalah statistik yang digunakan untuk menganalisis data dengan cara mendeskripsikan dan mengambarkan data yang telah terkumpul sebagaimana adanya tanpa bermaksud membuat kesimpulan yang berlaku untuk umum atau generalisasi. Analisis ini hanya merumuskan dan menyimpulkan data yaitu dengan cara membuka atau melihat data tabulasi yang ada dan menganalisisnya (Sugiyono, 2015). Untuk menganalisis data dalam penelitian ini maka digunakan rumus sebagai berikut:

$$
\mathrm{G}_{\mathrm{x}}=\frac{\mathrm{X} t-X t-1}{X t-1} \times 100 \%
$$

Dimana :

$\mathrm{G}_{\mathrm{x}} \quad=$ Laju perkembangan $\mathrm{X}$

$\mathrm{X}_{\mathrm{t}} \quad=$ Data $\mathrm{x}$ tahun tertent $\mathrm{u}$

$\mathrm{X}_{\mathrm{t}-1} \quad=$ Data $\mathrm{x}$ tahun sebelumnya

\section{Analisa kuantitatif}

Menurut Amir (2009), apabila data yang dikumpulkan itu berjumlah besar dan mudah diklasifikasikan kedalam kategori-kategori tertentu, maka analisis kuantitatiflah yang harus mengerjakan. Analisis kuantitatif itu disebut juga analisis statistik. Prosesnya dapat dibagi tiga tahap dan setiap tahap antara yang satu dengan lain berhubungan erat. Secara umum, 
analisis kuantitatif lebih mudah dan ringkas serta lebih cermat. Kenyataan ini lah yang menyebabkan analisis kuantitatif ini disebut juga analisis statistik.

Model persamaan regresi linear berganda dengan rumus sebagai berikut:

Dimana :

\section{IHSG $=$ F $($ K,INF,SB,JUB $)$}

IHSG = Indeks harga saham gabungan

$\mathrm{K} \quad=$ Kurs

$\mathrm{INF}=$ Inflasi

$\mathrm{SB} \quad=$ Suku bunga

JUB = Jumlah uang beredar

Adapun fungsi regresi linier berganda dapat ditulis sebagai berikut:

$$
\mathrm{IHSG}=\beta_{0}+\beta_{1} \mathrm{~K}_{1}+\beta_{2} \mathrm{INF}_{2}+\beta_{3} \mathrm{SB}_{3}+\beta_{4} \mathrm{JUB}_{4}+\mathrm{e}_{\mathrm{i}}
$$

Dimana :

\begin{tabular}{|c|c|}
\hline IHSG & $=$ Indeks harga saham gabungan \\
\hline$\beta_{0}$ & $=$ Konstanta \\
\hline$\beta_{1}, \beta_{2}, \beta_{3}, \beta_{4}$ & $=$ Koefisien regresi \\
\hline $\mathrm{K}$ & $=$ Kurs \\
\hline INF & $=$ Inflasi \\
\hline SB & $=$ Suku bunga \\
\hline JUB & $=$ Jumlah uang beredar \\
\hline & $=$ Error term \\
\hline
\end{tabular}

\section{HASIL DAN PEMBAHASAN}

\section{Perkembangan IHSG}

Rata-rata perkembangan IHSG tahun 1997-2018 sebesar 1,63\%. Perkembangan IHSG pada periode tahun 1997-2018 mengalami perubahan fluktuatif setiap tahunnya IHSG mengalami penurunan yang sangat tinggi terjadi pada tahun 2008 sebesar $-50,63 \%$ dengan nilai sebesar 1.355 point hal ini terjadi karena krisis keuangan global. Peningkatan yang sangat tinggi terjadi pada tahun 2009 sebesar 86,98\% dengan nilai sebesar 2.534 point hal ini terjadi karen investor terus melakukan pembelian yang selektif sehingga IHSG naik.

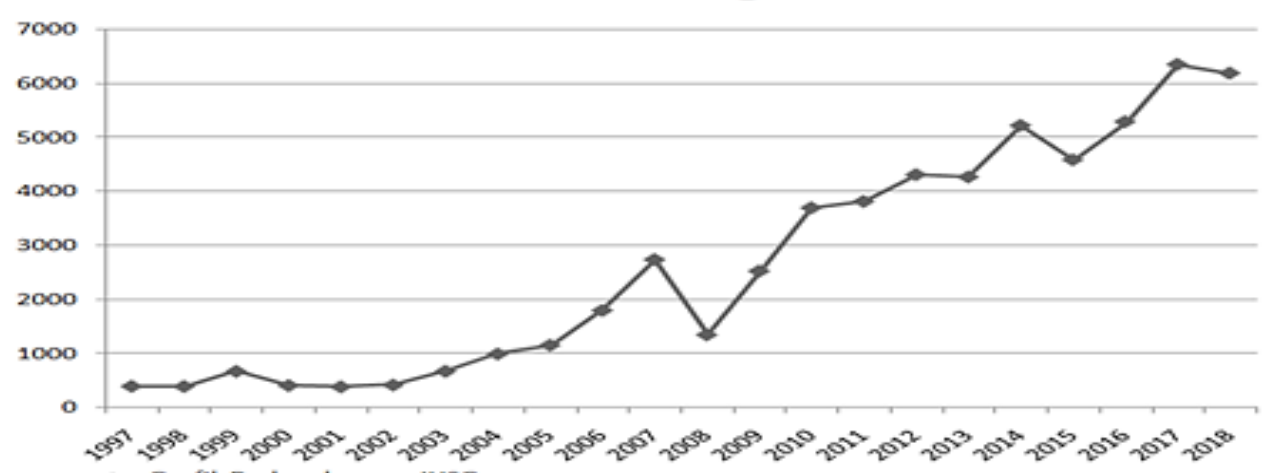

Sumber: Bank Indonesia, 2018 (Diolah) 


\section{Perkembangan kurs}

Rata-rata perkembangan kurs tahun 1997-2018 sebesar 4,69\%. Perkembangan kurs pada periode 1997-2018 mengalami fluktuatif setiap tahunnya kurs mengalami penurunan pada tahun 2009 yaitu sebesar 72,58\%, kemudian peningkatan kurs terjadi pada tahun 1998 yaitu sebesar 72,58\% hal ini dikarenakan pasca Orde Baru, Indonesia mengalami masa reformasi. Kepercayaan investor pun sedikit demi sedikit kembali, dan rupiah mulai menguat kembali.

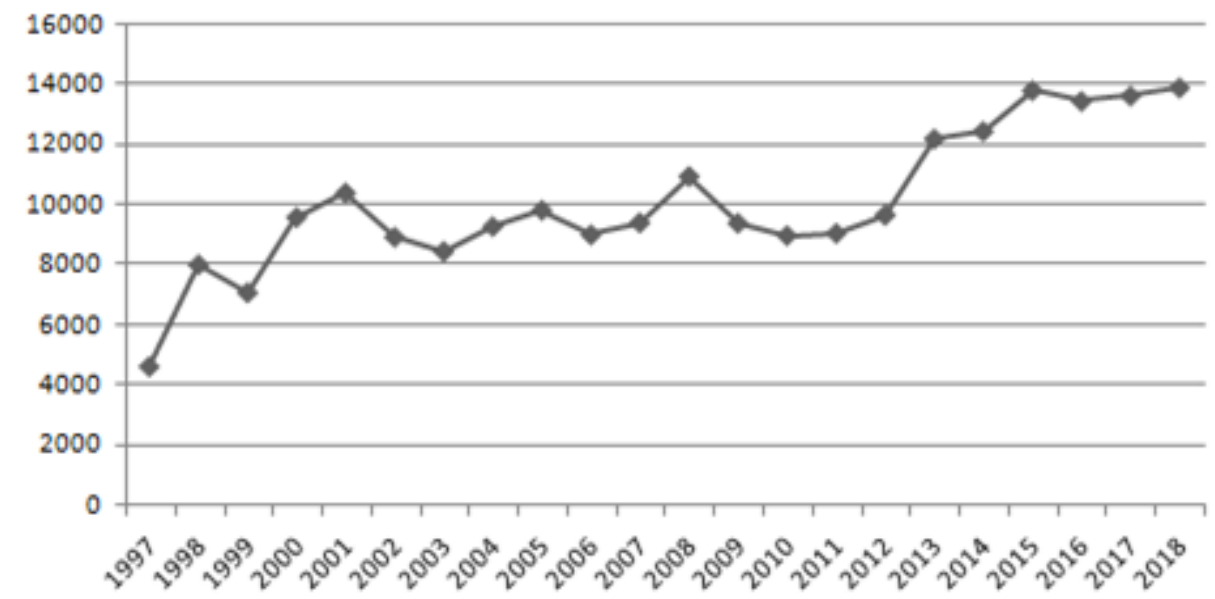

Sumber: Bank Indonesia, 2018 (diolah)

\section{Perkembangan inflasi}

Rata-rata perkembangan inflasi tahun 1997-2018 sebesar 10,12\%. Perkembangan inflasi pada periode 1997-2018 mengalami perubahan yang fluktuatif setiap tahunnya, inflasi yang tinggi terjadi pada tahun 1998 yaitu sebesar 77,6\% hal ini terjadi akibat lonjakan harga barang-barang yang diikuti melemahnya nilai tukar rupiah terhadap dolar Amerika Serikat membuat ekonomi Indonesia mengalami kontraksi. Inflasi yang sangat rendah terjadi pada tahun 1999 yaitu sebesar 2\% penyebabnya antara lain naiknya emas perhiasan, ikan segar, tarif listrik, tarif angkutan umum, bawang merah, dan kentang. Penyebab inflasi lainnya yakni kenaikan tarif angkutan udara, harga beras, tomat sayur, kelapa, daging sapi, dan mie.

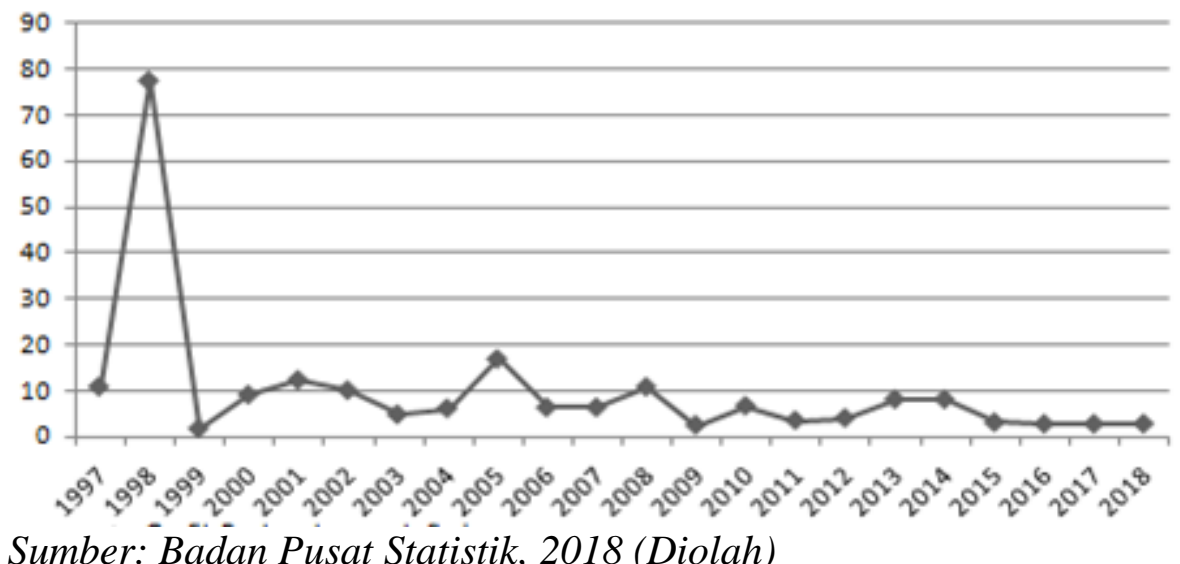

Sumber: Badan Pusat Statistik, 2018 (Diolah) 


\section{Perkembangan suku bunga}

Rata-rata perkemangan suku bunga tahun1997-2018 sebesar 5,75\%. Perkembangan suku bunga pada periode tahun 1997-2018 mengalami fluktuatif setiap tahunnya suku bunga mengalami penurunan pada tahun 2018 sebesar 1.25\%. Pada tahun 1998 meningkat sebesar $28,29 \%$.

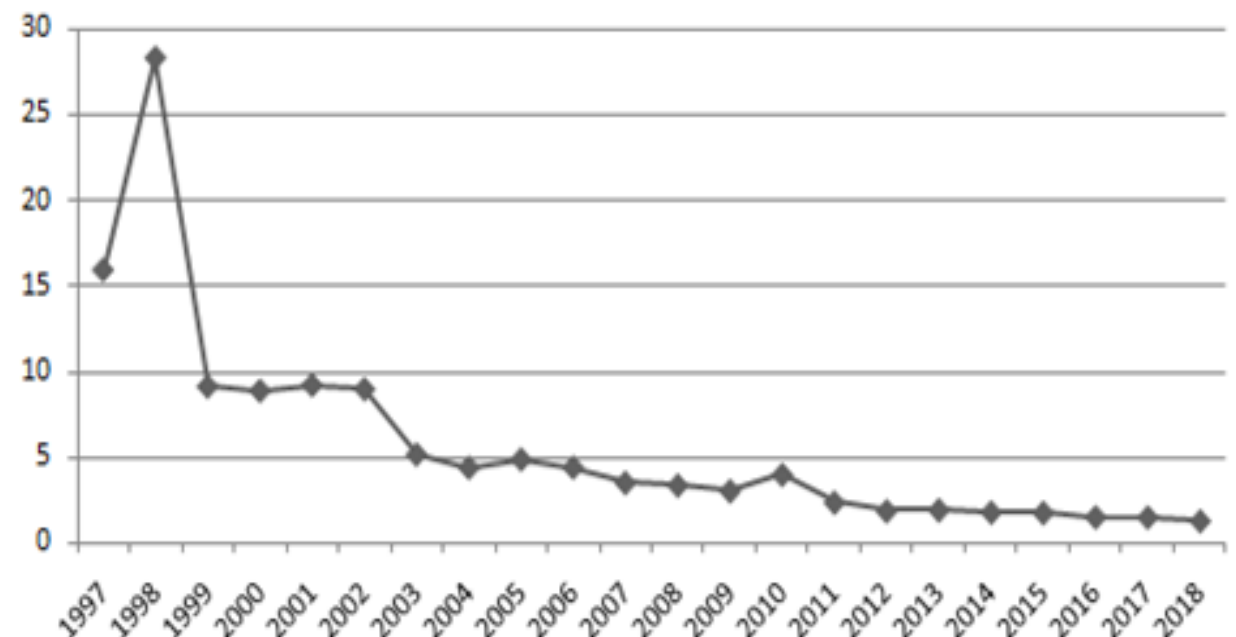

Sumber: Bank Indonesia, 2018 (Diolah)

\section{Perkembangan jumlah uang beredar}

Rata-rata perkembangan jumlah uang beredar sebesar 4,62\%. Perkembangan jumlah uang beredar pada periode 1997-2018 mengalami peningkatan setiap tahunnya, jumlah uang beredar yang tinggi terjadi pada tahun 1998 sebesar 62,34\%. Perkembangan yang rendah terjadi pada tahun 2002 sebesar 4,72\%.

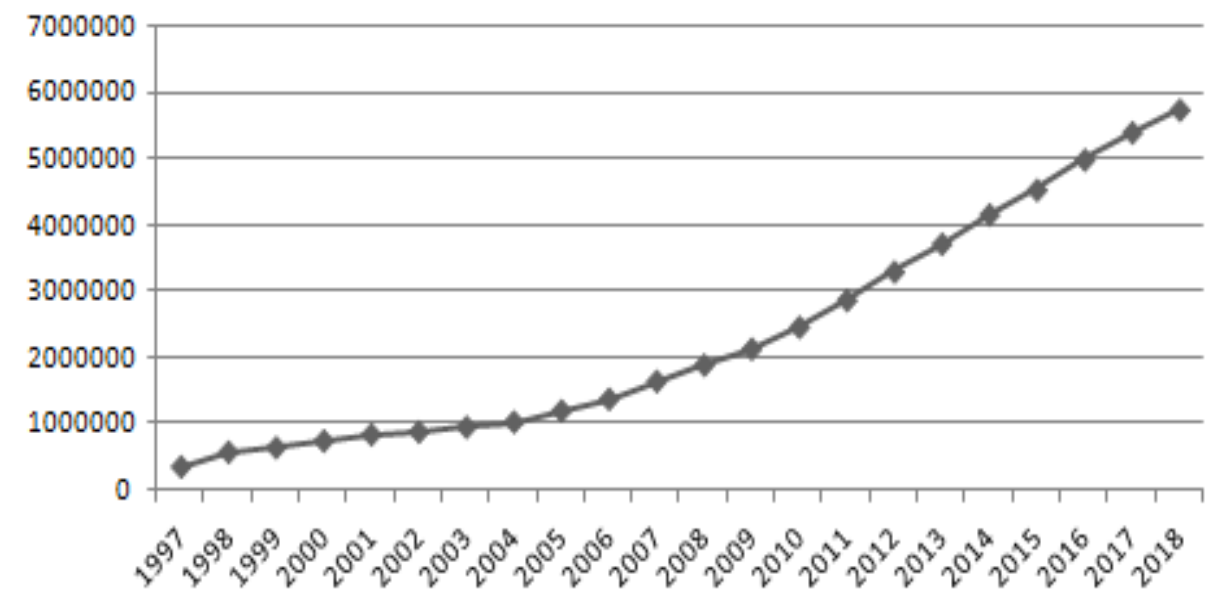

Sumber: Bank Indonesia, 2018 (diolah)

\section{Analisis kuantitatif}

Regresi linier berganda digunakan untuk melihat pengaruh kurs, inflasi, suku bunga, dan jumlah uang beredar terhadap indeks harga saham gabungan di Indonesia. Berikut hasil dari metode analisa dan perhitungan yang dilakukan melalui program Eviews 10 diperoleh regresi sebagai berikut. 
Tabel 1. Hasil analisis regresi berganda

\begin{tabular}{crrrr}
\hline Variable & Coefficient & Std. Error & t-Statistic & Prob. \\
\hline & & & & \\
C & 3013.631 & 677.0664 & 4.451013 & 0.0004 \\
KURS & -0.337686 & 0.073597 & -4.588316 & 0.0003 \\
INF & 29.31242 & 11.62567 & 2.521353 & 0.0220 \\
SB & -106.4664 & 35.06037 & -3.036661 & 0.0074 \\
JUB & 0.001423 & $8.97 \mathrm{E}-05$ & 15.85978 & 0.0000 \\
\hline \multicolumn{5}{l}{} \\
R-squared & 0.977601 & Mean dependent var & 2625.682 \\
Adjusted R-squared & 0.972331 & S.D. dependent var & 2091.762 \\
S.E. of regression & 347.9438 & Akaike info criterion & 14.73868 \\
Sum squared resid & 2058103. & Schwarz criterion & 14.98664 \\
Log likelihood & -157.1254 & Hannan-Quinn criter. & 14.79709 \\
F-statistic & 185.4930 & Durbin-Watson stat & 2.349596 \\
Prob(F-statistic) & 0.000000 & & \\
\hline
\end{tabular}

Sumber: Data diolah, 2018

Nilai konstanta sebesar 9.742, hal ini menunjukan bahwa jika S-I gap, neraca transaksi berjalan dan defisit anggaran adalah nol atau tidak berubah maka utang luar negeri indonesia meningkat sebesar 9,742 persen dengan asumsi jika variabel lain tidak brubah atau tetap.

\section{Pengaruh kurs terhadap IHSG}

Hasil regresi diketahui selama periode tahun 1997 - 2018, kurs berpengaruh negatif dan signifikan terhadap Indeks Harga Saham Gabungan (IHSG), dengan koefesien regresi sebesar -0,337686 yang berarti jika kurs naik (depresiasi) sebesar 1 persen akan menurunkan nilai Indeks Harga Saham Gabungan (IHSG) sebesar -0,33 persen dengan asumsi variabel lain tidak berubah atau tetap. Naiknya kurs asing mengakibatkan naiknya biaya import bahan baku untuk produksi perusahaan. Akibat semakin mahalnya biaya produksi perusahaan menjadikan laba yang diperoleh perusahaan menjadi semakin menurun. Sehingga investor akan berpikir dua kali bahkan mungkin tidak melirik perusahaan tersebut untuk menanamkan sahamnya karena investor khawatir akan memperoleh dividen yang relatif sanagt kecil. Akibatnya permintaan akan sahampun ikut menurun.

\section{Pengaruh inflasi terhadap IHSG}

Hasil regresi, inflasi berpengaruh positif dan signifikan terhadap Indeks Harga Saham Gabungan (IHSG) selama periode tahun 1997 - 2018, dengan koefesien regresi sebesar 29,31242 yang berarti kenaikan inflasi 1 persen akan menurunkan nilai Indeks Harga Saham Gabungan (IHSG) sebesar 29,31 persen dengan asumsi variabel lain tidak berubah atau tetap. Peningkatan inflasi secara relatif merupakan sinyal negatif bagi pemodal di pasar modal. Inflasi meningkatkan biaya perusahaan, jika peningkatan biaya produksi lebih tinggi dari peningkatan harga yang dapat dinikmati oleh perusahaan maka profit perusahaan akan turun. Jika profit perusahaan kecil, hal ini akan mengakibatkan para investor enggan menanamkan dananya di perusahaan tersebut sehingga harga saham menurun. 


\section{Pengaruh suku bunga terhadap IHSG}

Hasil regresi diketahui selama periode tahun 1997-2018, suku bunga berpengaruh negatif dan signifikan terhadap Indeks Harga Saham Gabungan (IHSG) dengan koefesien regresi sebesar -10,64664 yang berarti kenaikan suku bunga 1 persen akan menurunkan nilai Indeks Harga Saham Gabungan (IHSG) sebesar -10,64 persen dengan asumsi variabel lain tidak berubah atau tetap.

Jika suku bunga naik investor akan cenderum menyimpan uangnya di bank dikarenakan lebih menguntungkan daripada di pasar modal atau saham. Perubahan suku bunga akan memengaruhi harga saham secara terbalik, jika suku bunga meningkat, maka harga saham akan turun dan sebaliknya.hal ini sesuai dengan penjelasan tandelilin yaitu, jika suku bunga naik, maka return investasi yang terkait dengan suku bunga juga naik. Kondisi seperti ini dapat menarik minat investor yang sebelumnya berinvestasi di saham untuk memindahkan dananya dari saham ke deposito dan tabungan. Jika sebagian besar investor melakukan tindakan yang sama yaitu banyak investor yang menjual saham, maka harga saham akan turun.

\section{Pengaruh jumlah uang beredar terhadap IHSG}

Hasil regresi diketahui selama periode tahun 1997 - 2018, jumlah uang beredar berpengaruh positif dan signifikan terhadap Indeks Harga Saham Gabungan (IHSG), dengan koefesien regresi sebesar 0,001423 yang berarti kenaikan jumlah uang beredar 1 persen akan meningkatkan nilai Indeks Harga Saham Gabungan (IHSG) sebesar 0,001 persen dengan asumsi variabel lain tidak berubah atau tetap.

Jika terjadi peningkatan jumlah uang beredar sebagian besar jumlah uang beredar tersebut akan diinvestasikan dengan membeli saham, kenaikan jumlah uang beredar di masyarakat selain dibelanjakan oleh masyarakat dan bagi investor di belanjakan di saham, secara keseluruhan dalam perekomomian akan terjadi peningkatan permintaan terhadap saham dan bila terjadi kenaikan permintaan terhadap saham maka harga saham itu akan meningkat hal ini dicerminkan dengan kenaikan ihsg. Hal ini sesuai dengan penjelasan samsul yaitu, jika jumlah uang beredar mengalami peningkatan maka indes harga saham gabungan akan naik sehingga pasar modal akan mengalami peningkatan, begitupula sebaliknya

\section{Uji asumsi klasik}

\section{Uji multikolinieritas}

Uji Multikolinearitas dilakukan untuk menguji atau tidaknya hubungan linear yang sempurna atau pasti antara beberapa atau semua variabel yang menjelaskan model regresi. Jika koefisien koreasi antara masing-masing variabel bebas lebih kecil dari 10 , berarti model tersebut mampu menjelaskan dengan baik perilaku variabel dependen.

Berdasarkan hasil olahan data nilai Centered VIF variabel kurs sebesar 5.132204, variabel inflasi sebesar 5.673203, suku bunga sebesar 8.246641 dan variabel jumlah uang beredar sebesar 4.192192 dilihat dari nilai VIF kurang dari 10 maka dapat disimpulkan bahwa tidak terjadi multikolinieritas dan hal tersebut menunjukkan adanya hubungan linier yang sempurna diantara beberapa atau semua variabel independent dari model regresi. 
Tabel 2. Uji multikolinieritas

\begin{tabular}{cccc}
\hline Variable & $\begin{array}{c}\text { Coefficient } \\
\text { Variance }\end{array}$ & $\begin{array}{c}\text { Uncentered } \\
\text { VIF }\end{array}$ & $\begin{array}{c}\text { Centered } \\
\text { VIF }\end{array}$ \\
\hline C & & & \\
KURS & 458418.9 & 83.30420 & NA \\
INF & 0.005416 & 105.5134 & 5.132204 \\
SB & 135.1562 & 8.190378 & 5.673203 \\
JUB & 1229.229 & 15.64020 & 8.246641 \\
\hline
\end{tabular}

Sumber: Data diolah, 2018

\section{Uji heteroskedastisitas}

Merupakan salah satu asumsi OLS jika variabel residualnya tidak sama. Uji heteroskedastisitas dimaksud untuk menguji varian gangguan (e) tidak mengalami penyebaran yang sama, sehingga model yang sudah dibuat menjadi kurang efisien.

Tabel 3. Uji heteroskedastisitas

\begin{tabular}{llll}
\hline F-statistic & 0.446362 & Prob. F(14,7) & 0.9057 \\
Obs ${ }^{*}$ R-squared & 10.37654 & Prob. Chi-Square(14) & 0.7342 \\
Scaled explained SS & 6.452270 & Prob. Chi-Square(14) & 0.9538 \\
\hline
\end{tabular}

Sumber: Data diolah, 2018

Dari tabel diatas niali chi-square hitung sebesar 0.9538 yang diperoleh dari Obs*Rsquared yaitu jumlah observasi dikalikan dengan koefisien determinasi. Sedangkan nilai tabel prob. chi-square pada model ialah $0.9538>\alpha=5 \%(0,05)$ Karena chi-square hitung lebih besar dari nilai tabel chi-square maka dapat disimpulkan tidak ada masalah heteroskedastisitas.

\section{Uji autokorelasi}

Uji ini digunakan untuk mengetahui ada atau tidaknya autokorelasi. Autokorelasi merupakan suatu keadaan dimana variabel independen pada periode tertentu berkorelasi dengan variabel independen pada periode lainnya, dengan kata lain variabel independen tidak random atau korelasi diantara variabel yang berurutan dari data time series. Uji yang digunakan adalah Breusch-Godfrey Serial Correlalation LM Test. Berikut ini hasil uji autokorelasi:

Tabel 4. Uji Autokorelasi

\begin{tabular}{llll} 
F-statistic & 2.686588 & Prob. F(2,15) & 0.1006 \\
Obs*R-squared & 5.802231 & Prob. Chi-Square(2) & 0.0550 \\
\hline
\end{tabular}

Sumber: Data diolah, 2018

Dari data diatas dapat diperoleh nilai Obs*R-squared $(0,0550)>$ nilai tabel chi-square $\left(\mathrm{X}^{2}\right)$ sebesar $\alpha-5 \%$ (0.05) artinya model tidak terdapat autokorelasi.

\section{Uji normalitas}

Uji ini dilakukan untuk melihat apakah model regresi variabel penganggu atau residulnya memiliki distribusi normal. Uji ini dilakukan dengan membandingkan nilai Jarque-Berra dengan nilai tabel chi-square $\left(\mathrm{X}^{2}\right)$. 

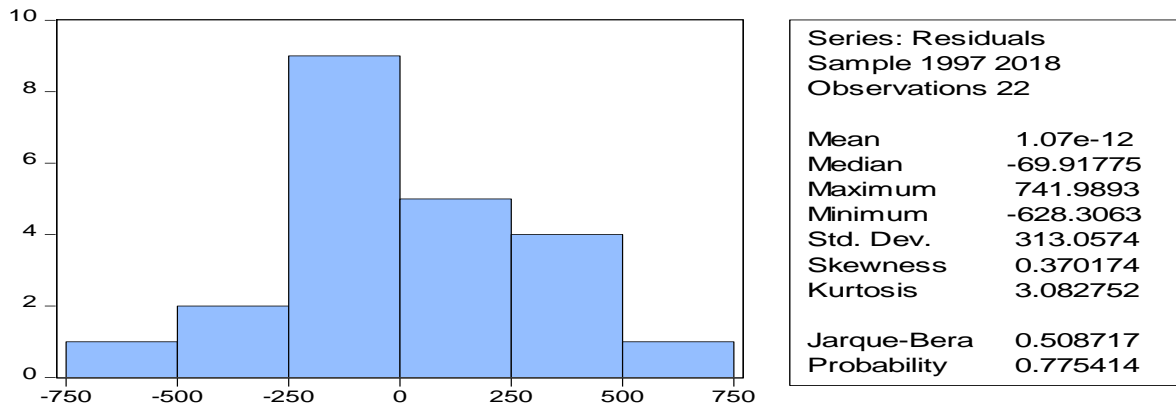

Dari gambar diatas diperoleh nilai prob.(0.775414) > nilai tabel chi-square $\left(\mathrm{X}^{2}\right)$ sebesar $(0,05)$ artinya model lolos dari ketidak normalan distribusi residual.

\section{Pengujian hipotesis}

\section{Pengujian secara parsial (Uji t)}

Untuk mengetahui pengaruh variabel indevenden terhadap variabel devenden secara individu maka digunakan uji t. untuk menguji hipotesis maka dilakukan uji t dengan tingkat signifikan 5\%,. dari hasil regresi diketahui t hitung masing-masing variabel adalaha sebagai berikut:

Tabel 5. Koefisien variabel bebas

\begin{tabular}{crrrr}
\hline Variable & Coefficient & Std. Error & t-Statistic & Prob. \\
\hline & & & & \\
C & 3013.631 & 677.0664 & 4.451013 & 0.0004 \\
KURS & -0.337686 & 0.073597 & -4.588316 & 0.0003 \\
INF & 29.31242 & 11.62567 & 2.521353 & 0.0220 \\
SB & -106.4664 & 35.06037 & -3.036661 & 0.0074 \\
JUB & 0.001423 & $8.97 \mathrm{E}-05$ & 15.85978 & 0.0000 \\
\hline
\end{tabular}

\section{Sumber: Data diolah, 2018}

Berdasarkan hasil olahan data nilai prob. kurs dan suku bunga lebih kecil dari nilai $\alpha$ $5 \%(0,05)$ dan t-statistik bernilai negatif. Hal ini menunjukkan bahwa kurs dan suku bunga berpengaruh negatif dan signifikan terhadap indeks harga saham gabungan. Sedangkan nilai prob. inflasi dan jumlah uang beredar lebih kecil dari nilai $\alpha 5 \%(0,05)$ dan t-statistik bernilai positif. Hal ini menunjukkan bahwa inflasi dan julah uang beredar berpengaruh positif dan signifikan terhadap infdeks harga saham gabungan.

\section{Pengujian secara simultan (Uji F)}

Uji $\mathrm{F}$ adalah pengujian terhadap koefisien regresi secara simultan. Pengujian ini dilakukan untuk mengetahui pengaruh semua variabel independen yang terdapat di dalam model secara bersama-sama (simultan) terhadap variabel dependen. Uji F dalam penelitian ini digunakan untuk menguji signifikasi pengaruh variabel independen terhadap variabel dependen secara simultan. Menurut Sugiyono (2014)

Uji F digunakan untuk mengetahui apakah variabel kurs, inflasi, suku bunga dan jumlah uang beredar berpengaruh terhadap indeks harga saham gabungan. Dari hasil regresi dengan menggunakan Eviews 10 diperoleh nilai $\mathrm{F}$ hitung sebesar (0,000000) dengan 
membandingkan antara $\mathrm{F}$ hitung dengan $\mathrm{F}$ tabel dimana $\alpha=5 \%$ dengan nilai $\mathrm{F}$ tabel sebesar $(0,5 \%)$. Dari nilai tersebut dimana $F$ hitunglebih kecil dari $F$ tabel $(0,000000<$ $0,05 \%)$, artinya adalah $\mathrm{H}_{0}$ ditolak, maka dapat disimpulkan bahwa kurs, inflasi, suku bunga dan jumlah uang beredar secara bersama-sama berpengaruh secara signifikan terhadap IHSG.

\section{Koefisien determinasi $\left(\mathbf{R}^{2}\right)$}

Berdasarkan pengujian model diperoleh koofisien determinan $\mathrm{R}^{2}$, semakin tinggi koofisien determinasi atau mendekati satu maka akan semakin baik model tersebut dalam arti semakin besar kemampuan variabel indevenden sangat mempengaruhi perubahan variabel devenden. Setelah dilakukan olahan data dengan Eviews 10 diperoleh nilai koefisien determinan $\mathrm{R}^{2}$ sebesar 0.977601 artinya bahwa 97\% kontribusi variabel indevenden terhadap variabel devenden, sedangkan sisanya 3\% lagi disebabkan oleh variabel lain yang tidak dimasukkan kedalam penelitian ini.

\section{KESIMPULAN DAN SARAN}

\section{Kesimpulan}

Perkembangan indeks harga saham gabungan selama periode tahun 1997-2018 mengalami fluktuasi dan cenderung meningkat, rata-rata perkembangan indeks harga saham gabungan adalah sebesar 0,22 persen per tahun. Perkembangan kurs selama periode tahun 1997-2018 mengalami fluktuasi, rata-rata perkembangan adalah sebesar 2,57 persen per tahun. Perkembangan inflasi selama periode tahun 1997-2018 mengalami fluktuasi, rata-rata perkembangan adalah sebesar $-0,90$ persen per tahun. Perkembangan suku bunga selama periode tahun 1997-2018 mengalami fluktuasi, rata-rata perkembangan adalah sebesar -2,73 persen per tahun. Perkembangan jumlah uang beredar selama periode tahun 1997-2018 mengalami fluktuasi, rata-rata sebesar 0,06 persen per tahun. Secara parsial, dari hasil regresi kurs berpengaruh negatif dan signifikan terhadap IHSG, inflasi berpengaruh positif dan signifikan terhadap IHSG, suku bunga berpengaruh negatif dan signifikan terhadap IHSG dan jumlah uang beredar berpengaruh positif dan signifikan terhadap IHSG. Secara simultan, dari hasil regresi didapatkan bahwa kurs, inflasi, suku bunga dan jumlah uang beredar berpengaruh signifikan terhadap IHSG.

\section{Saran}

Berdasarkan kesimpulan di atas, maka saran-saran yang dapat diberikan melalui hasil penelitian ini baik kepada investor, perusahaan maupun untuk pengembangan penelitian yang lebih lanjut adalah sebagai berikut: Untuk menjaga nilai indeks harga saham, bagaimana kebijakan moneter bisa mengendalikan nilai tukar rupiah tidak terdepresiasi, serta bagaimana cara mengendalikan laju inflasi, bagaimana cara mengendalikan tingkat suku bunga tidak telalu tajam peningkatannya yang menyebabkan ihsg turun serta bagaimana cara pengendalian jumlah uang beredar agar tetap stabil. Perusahaan sebaiknya lebih memperhatikan perubahan kurs, inflasi, suku bunga, dan jumlah uang beredar dunia 
karena faktor-faktor tersebut merupakan faktor makro ekonomi yang berpengaruh terhadap IHSG dan dapat berpengaruh vital akan besar-kecilnya beban perusahaan di kemudian hari.

\section{DAFTAR PUSTAKA}

Amir, Taufiq, (2009). Inovasi pendidikan melalui problem based learning. Kencana Prenada Media Group: Jakarta.

Darmadji dkk, (2012). Pasar modal di Indonesia. Salemba Empat: Jakarta.

Hastuti.D; M.Edhie,Purnawan;\& S.Sunargo. (2018). Pengaruh variabel-variabel di sektor riil dan perbankan terhadap Shock Credit Default Swap (CDS) di Indonesia, $e$ Journal Perdagangan Industri dan Moneter, 6(2), 62-80

Husnan, (1993). Dasar-dasar teori portofolio \& analisis sekuritas. UPP STIM YKPN: Yogyakarta.

Husnan, (2015). Dasar-dasar teori portofolio \& analisis sekuritas edisi 5. UPP STIM YKPN: Yogyakarta.

Martalena dan Malinda, 2011. Pengantar pasar modal. Andi Publisher: Jakarta.

Samsul, (2008). Pasar modal dan manajemen portofolio. Erlangga: Jakarta.

Samsul, (2008). Pasar modal dan manajemen portofolio. Erlangga: Jakarta.

Sugiyono, (2014). Metode penelitian pendidikan pendekatan kuantitatif, kualitatif, dan $R \& D$. Alfabeta: Bandung.

Sugiyono, (2015). Metode penelitian kombinasi (Mix Methods). Alfabeta: Bandung.

Sunariyah, (2006). Pengantar pengetahuan pasar modal. UPT STIM YKPN: Yogyakarta.

Yudiarti,T; E Emilia; \& C Mustika. (2018).Pengaruh utang luar negeri, tingkat suku bunga dan neraca transaksi berjalan terhadap nilai tukar Rupiah terhadap Dolar Amerika Serikat, e-Jurnal Perdagangan Industri dan Moneter, 6 (1), 14-22 